\title{
Colorectal Cancer and Alcohol Consumption-Populations to Molecules
}

\author{
Marco Rossi, Muhammad Jahanzaib Anwar ${ }^{(\mathbb{D}}$, Ahmad Usman, Ali Keshavarzian and \\ Faraz Bishehsari * \\ Division of Digestive Diseases, Hepatology, and Nutrition, Department of Internal Medicine, \\ Rush University Medical Center, Chicago, IL 60612, USA; Marco_Rossi@rush.edu (M.R.); \\ docjazzya@gmail.com (M.J.A.); Usman_Ahmad@rush.edu (A.U.); Ali_keshavarzian@rush.edu (A.K.) \\ * Correspondence: faraz_bishehsari@rush.edu; Tel.: +1-312-563-4092
}

Received: 19 December 2017; Accepted: 24 January 2018; Published: 30 January 2018

\begin{abstract}
Colorectal cancer (CRC) is a major cause of morbidity and mortality, being the third most common cancer diagnosed in both men and women in the world. Several environmental and habitual factors have been associated with the CRC risk. Alcohol intake, a common and rising habit of modern society, is one of the major risk factors for development of CRC. Here, we will summarize the evidence linking alcohol with colon carcinogenesis and possible underlying mechanisms. Some epidemiologic studies suggest that even moderate drinking increases the CRC risk. Metabolism of alcohol involves ethanol conversion to its metabolites that could exert carcinogenic effects in the colon. Production of ethanol metabolites can be affected by the colon microbiota, another recently recognized mediating factor to colon carcinogenesis. The generation of acetaldehyde and alcohol's other metabolites leads to activation of cancer promoting cascades, such as DNA-adduct formation, oxidative stress and lipid peroxidation, epigenetic alterations, epithelial barrier dysfunction, and immune modulatory effects. Not only does alcohol induce its toxic effect through carcinogenic metabolites, but alcoholics themselves are predisposed to a poor diet, low in folate and fiber, and circadian disruption, which could further augment alcohol-induced colon carcinogenesis.
\end{abstract}

Keywords: alcohol; CRC; polyposis; metabolism; epigenetics; immunity

\section{Introduction}

Colorectal cancer (CRC) is the third most commonly diagnosed cancer among men, and the second most diagnosed among women worldwide [1]. It also constitutes a significant proportion of the global burden of cancer morbidity and mortality, being the 4th most common cause of cancer mortality, and accounting for 600,000 deaths annually [1,2]. With its relatively high incidence, CRC remains one of the major areas of healthcare spending, with the mean cost of disease management in the first year of diagnosis being around \$32,648 [3]. The occurrence of CRC occurrence is closely linked to the environment and Western lifestyle [4]. Therefore, recognizing and addressing environmental factors contributing to the disease development and progression could reduce the CRC burden [4]. Alcohol consumption, a lifestyle habit commonly associated with Western lifestyle, is a major contributor to colon carcinogenesis [5]. Given the high prevalence of alcohol drinking and high incidence of CRC worldwide, the contribution of alcohol consumption toward the development of CRC, particularly in the developed countries, constitutes a significant proportion of the condition's global burden [6]. It is estimated that alcohol increases the chance of CRC by $60 \%$ [7]. Alcohol has numerous direct and indirect effects that contribute toward carcinogenesis [8-10]. Its metabolism can be either oxidative or non-oxidative, producing acetaldehyde as well as a number of other metabolites [11]. Alcohol, along with its metabolites, can promote carcinogenesis through numerous mechanisms $[8,9,12]$. 
These mechanisms cause genetic, epigenetic, biochemical, and immunological abnormalities, leading to chronic inflammation and cancer formation $[5,9,10,13]$. Here, we highlight the most updated epidemiological evidence studies on alcohol and the risk of CRC. We will then review the mechanisms by which chronic alcohol intake may lead to CRC formation. Understanding mechanisms underlying the alcohol induced CRC will provide us with opportunities to identify factors/pathways that promote the alcohol's effect. This would help us identify alcohol drinkers at risk for CRC formation, develop personalized preventive strategies, and finally, discover therapeutic interventions targeting pathways responsible for the increased susceptibility to carcinogenesis effects of alcohol.

\section{The Epidemiology of Alcohol and Colon Carcinogenesis}

\subsection{Alcohol and CRC}

Alcohol intake, even in small amounts, has been proposed to be associated with an increased risk of CRC [14-16]. The association of alcohol consumption and CRC risk is dose-dependent $[14,17,18]$. CRC risk is particularly remarkable with heavy drinking, while data on the risk of CRC due to light to moderate drinking is inconsistent $[14,17,18]$. A recent meta-analysis of literature from 1966 to 2013 shows an overall relative risk (RR) of 1.21 (95\% CI, 1.01-1.46) for subjects who drink $56.5 \mathrm{~g} /$ day [14]. Similarly, another meta-analysis focusing on cohort studies from North America and Europe found that subjects consuming $\geq 50 \mathrm{~g} /$ day had an overall CRC RR of 1.52 (95\% CI, 1.27-1.81) [16]. Although data on binge alcohol consumption and CRC risk is limited, mechanistically, this is possible, as binge drinking has been shown to increase CYP2E1 and HIF-1 $\alpha$ levels in human samples [19]. In addition to CRC risk, one German study reported on an increased CRC mortality from heavy drinking ( $>50 \mathrm{~g} /$ day for men, $>25 \mathrm{~g} /$ day for women, $\mathrm{HR}=1.37,95 \% \mathrm{CI}, 1.06-1.78, p=0.015$ ) [20], though these findings were not replicated by another recent large study [21]. Nonetheless, a meta-analysis supported an association between heavy alcohol drinking ( $\geq 50 \mathrm{~g} /$ day of ethanol) and CRC mortality [14]. Several mechanisms have been proposed to explain the alcohol effect on cancer mortality, which includes effects of alcohol on tumor growth via insulin signaling, selection for aggressive clones, impairment of host defenses, poor diet, and patient noncompliance [22-25].

Other factors can modulate alcohol's effects on CRC risk [26]. One such factor is a family history of the disease [26]. One study found that, with an alcohol consumption of $\geq 30 \mathrm{~g} /$ day, the RR of CRC significantly increased from 1.20 to 2.80 when a family history of CRC was present [26]. Another modulatory factor could be sex; among subjects that drink 12.5-50 g/day, males have a CRC RR of 1.10 (95\% CI, 1.03-1.18) while female subjects have a RR of 0.87 (95\% CI, 0.65-1.16) [14]. Body mass index (BMI) and weight could also interact with alcohol on CRC risk. A Canadian study reported that, for subjects who consumed an alcohol beverage at least once a week for 6 months or longer, those with a BMI $<30$ had an overall CRC OR of 0.8 (95\% CI, 0.60-1.10) [27]. But, those with a BMI > 30 had an overall CRC OR of $2.2\left(95 \%\right.$ CI, 1.20-4.00, $\left.p_{\text {trend }}<0.05\right)$ [27]. A fourth factor is race, especially with regard to CRC screening [28,29]. In New Mexico, one study found a significant difference in the CRC screening of Hispanic females (ages $\geq 50$ years) who were at risk of drinking more than one alcoholic drink a day compared to Caucasian females of the same age and alcohol risk $(p<0.01$, Chi-square analysis) [29]. Despite the known interaction of smoking and alcohol in malignancies of upper gastrointestinal tract, there is little evidence that smoking modulates the risk of alcohol-induced CRC. Therefore, although smoking is a major CRC risk factor, a connection with alcohol cannot currently be made [30].

Alcohol's influence could also vary based on individual differences in alcohol metabolisms. Alcohol's impact on CRC has been widely implicated in Asian populations, due to the prevalence of genetic polymorphisms in enzymes involved in alcohol metabolism [31-33]. For example, ADH1B polymorphisms have been associated with an increased risk of CRC [34]. In a recent meta-analysis, the ADH1B Arg47His polymorphism was determined to have a CRC OR of 1.18 (95\% CI, 1.01-1.36, $p=0.03$ ) [34]. Besides those associated with ADH1B, associations between CRC risk and other 
polymorphisms commonly found in Asian populations, like those associated with ALDH2, have been inconsistent [35].

Alcohol consumption may not equally affect all areas of the colorectum [36,37]. Multiple studies show that, for high alcohol consumption, the highest cancer hazard ratio (HR) resides in the rectum [36,37]. One such study found that, for an average lifetime consumption rate of $>60 \mathrm{~g} /$ day, the $\mathrm{HR}=2.59(95 \% \mathrm{CI}, 1.62-4.13)$ for the rectum, $\mathrm{HR}=2.22$ (95\% CI, 1.20-4.13) for the distal colon, and $\mathrm{HR}=1.22$ (95\% CI, 0.59-2.51) for the proximal colon [37]. This trend of the HR being the highest in the rectum, lower in the distal colon, and the lowest in the proximal colon, was reproduced in a Dutch study for subjects that consume $\geq 30 \mathrm{~g} /$ day [36].

\subsection{Alcohol and Polyps}

CRC rises from pre-cancerous neoplastic lesions in the colon, called polyps. Several studies support a positive association between alcohol consumption and the risk of adenomatous polyp formation [38-41]. A recent meta-analysis showed an increased risk of adenoma, even with light to moderate drinking [42]. The association of alcohol intake with colonic polyps could be particularly strong for larger adenomas [40]. Similar to CRC, the link of alcohol and polyp risk could be dose dependent; consumption of seven or more drinks/weeks increased risk of adenoma formation by odds ratio of 2.04 (95\% CI, 1.28-3.26) [38]. Besides adenomatous polyps, alcohol has been recently shown to increase the risk of formation of serrated polyps as well [43]. Serrated polyps are less common than conventional adenomas, and have been recognized as the alternative pathway to CRC $[43,44]$. The relative risk of serrated polyp formation is 1.30 (95\% CI, 1.15-1.48), when comparing drinkers that drink high vs low amounts of alcohol [43]. The effects of alcohol on polyp formation could be possibly modified by other demographic factors, including a history of previous adenomas [45]. For example, among heavy drinkers that consumed $>50 \mathrm{~g}$ alcohol/day, the percentage of cases that developed a high-risk adenoma or CRC was $72 \%$ when those heavy drinkers had at least one previous high-risk adenoma or cancer; there was a $57 \%$ development of these conditions without a prior high-risk adenoma or cancer $\left(p<0.01\right.$, global $\chi^{2}$ test) [45]. The association of alcohol intake with colonic polyps propose an association of colonic polyps with alcoholic liver disease (ALD), a well-established sequela from alcohol [46]. In a Canadian study, 80 orthotopic liver transplant (OLT) patients were screened for polyps before and after the transplant [46]. It was found that those with a history of ALD were 11 times more likely to develop post-transplant polyps in the colon (OR $=11.3,95 \%$ CI 3.2-39.4, $p<0.001$ ) [46]. We could not find any studies that directly test association of binge alcohol consumption and the CRC risk. Such an association seems likely, given that binge alcohol consumption could result in ALD, and that ALD is an established risk factor for colonic neoplasm.

Overall, most studies agree on recognizing chronic alcohol consumption as a risk factor for colorectal polyposis and cancer formation, suggesting the contribution of alcohol to colorectal carcinogenesis $[8,9,12]$. The risk is even stronger when combined with other risk factors, like obesity $[27,38,47-49]$. In the following section, we will discuss possible molecular mechanisms that could mediate alcohol's effects on CRC.

\section{The Metabolism of Ethanol}

\subsection{General Metabolism}

The overall metabolic processes of ethanol can be subdivided into two main categories: oxidative and non-oxidative metabolism (Figure 1) [11]. The majority of ethanol metabolism consists of oxidative metabolism, in which ethanol is converted to acetaldehyde either by alcohol dehydrogenase (ADH), cytochrome P450 2E1 (CYP2E1), or bacterial catalase [11,50-52]. Acetaldehyde is then converted into acetic acid via aldehyde dehydrogenase (ALDH), CYP2E1, or the combination of aldehyde oxidase $(\mathrm{AO})$ and xanthine oxidase $(\mathrm{XO})[11,50,53]$. It must be noted that metabolism through CYP2E1 is a large producer of reactive oxygen species (ROS), which can affect many mechanisms [11,12]. 
Of ethanol's metabolites, acetaldehyde is widely considered to be the most potent in colorectal carcinogenesis through its interactions with various cellular and biochemical processes $[10,12,51,53-55]$. Non-oxidative metabolism, although occurring at lower rates, has a range of physiological influence that can be quite profound due to the wide variety of metabolites produced [11,56]. This variety is derived from the ability of ethanol to "insert" itself into the structures of significant biochemical molecules [56]. For example, ethanol can undergo an enzymatic esterification with fatty acids (FA) to produce fatty acid ethyl esters (FAEE) via FAEE synthase (FAEES) [56]. Another example is the enzymatic production of ethyl glucuronide (EtG) from uridine $5^{\prime}$-diphospho-glucuronic acid (UGT) and ethanol [56].

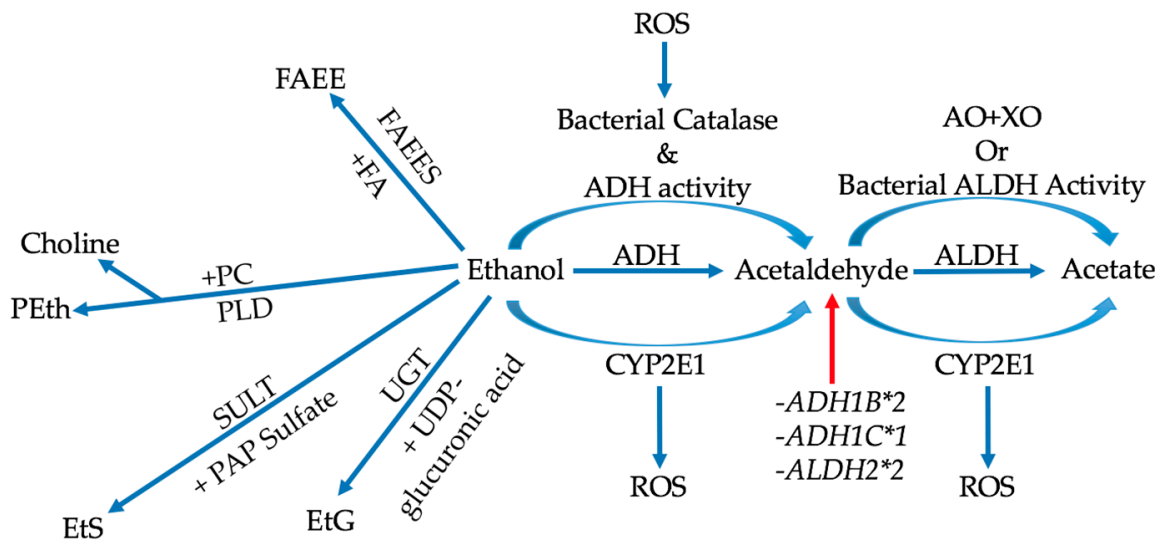

Figure 1. The majority of ethanol metabolism is oxidative where carcinogenic acetaldehyde is produced via alcohol dehydrogenase (ADH), CYP2E1, or bacterial catalases. The acetaldehyde is reduced by being converted to acetic acid by aldehyde dehydrogenase (ALDH), CYP2E1, or the combination of aldehyde oxidase (AO) and xanthine oxidase (XO). Conversion with CYP2E1 tends to produce reactive oxygen species (ROS), adding to carcinogenesis. Polymorphisms in the ADH and ALDH enzymes increase acetaldehyde concentrations (red arrow). Non-oxidative metabolism leads to the production of metabolites using various types of molecules. In the case of nucleotides, EtG and EtS are produced. For lipids, PEth and FAEE are produced. EtS = ethyl sulfate; SULT = sulfotransferase; PAP Sulfate $=3^{\prime}$-phosphoadenosine $-5^{\prime}$-phospho sulfate; $\mathrm{PEth}=$ phosphatidylethanol; $\mathrm{PC}=$ phosphatidylcholine; PLD $=$ phospholipase D.

\subsection{Enzyme Polymorphisms and Bacterial Metabolism}

Metabolic variations in production or degradation of alcohol metabolites could affect their availability and, as such, modulate alcohol effect on the tissue [8,54,57]. Genetic polymorphisms, like $A D H 1 B^{*} 2$ and $A D H 1 C^{*} 1$, increase the activity of alcohol dehydrogenase and, thus, increase the amount of acetaldehyde present $[11,54]$. On the other hand, two ALDH2*2 alleles can render the aldehyde dehydrogenase enzyme nearly inactive, preventing acetaldehyde's degradation [8]. Besides genetic variations, bacterial metabolism of ethanol also increases the amount of acetaldehyde formed in the colon [11,51,58,59]. Bacterial catalase can produce acetaldehyde from ethanol like alcohol dehydrogenase [58,60,61]. Certain bacteria in the colon, such as the Enterobacteriaceae, also have ADH and ALDH activities [62]. However, bacterial ALDH activities tend to be less than their ADH activities, allowing colonic acetaldehyde to accumulate as ethanol consumption increases [59,62-64]. Acetaldehyde production by anaerobic bacteria in the colon, such as Ruminococcus and Bifidobacterium, can also increase upon exposure to ROS, resulting in a vicious cycle of accumulating carcinogens [59]. With these bacterial production methods present, local acetaldehyde concentrations in the colon increase past the minimum mutagenic concentration (MMC), and greatly contribute to carcinogenesis [58-61]. 


\section{Genetic Stability, Epigenetic Modifications, and Mutation}

\subsection{Direct DNA Damage}

There are quite a few ways in which ethanol and its metabolites can affect genetic stability and expression that may lead to colorectal carcinogenesis [10,12,55,65-67]. Alcohol metabolites can directly affect DNA stability [12,68]. Acetaldehyde can bind to deoxynucleotides to form DNA adducts [12]. In addition, malondialdehyde (MDA) and 4-hydroxynoneal (4-NHE), metabolites from ROS-induced lipid peroxidation, can also form DNA adducts [12,55]. Thus, metabolic processes increasing ROS formation can also instigate this direct DNA damage and encourage colorectal carcinogenesis. In fact, in a study of 46 patients, those that were alcoholics formed more ethano-DNA adducts than the non-drinking controls [69]. In this study, the correlation between the formation of these adducts and colorectal cancer formation was made, as hyperproliferation of the colonic mucosa was observed [69]. Besides direct DNA damage, there are also indirect modalities through which ethanol can disturb genomic integrity [10,12,55,65-67].

\subsection{Indirect DNA Instability}

Ethanol metabolism can affect colorectal carcinogenesis by influencing single-carbon metabolism (Figure 2) [10,70,71]. Under normal circumstances, homocysteine is converted to methionine through either methionine synthase (MTR) or betaine homocysteine methyltransferase (BHMT) [10]. That methionine is converted to $S$-adenosylmethionine (SAMe) by methionine adenosyl transferase (MAT) [10]. In turn, methyl groups from SAMe are used by DNA methyltransferases (DNMTs) to methylate deoxynucleotides [10]. MTR, MAT, and DNMTs are some of the key enzymes in single-carbon metabolism that regulate DNA methylation [10]. Ethanol and its metabolites can affect the activities of all of these enzymes [10]. It was found that the activities of these enzymes are reduced with alcohol and/or acetaldehyde [10]. Through the inhibition of these enzymes, ethanol metabolism decreases DNA methylation and dysregulates epigenetic patterns [10]. This overall decrease in DNA methylation, or global DNA hypomethylation, has been widely shown in CRC [70,71]. For example, hypomethylation of long interspersed nuclear element-1 (LINE-1) sequences in the CRC tissues of 77 patients was shown to increase MET expression in metastases [71]. To further emphasize the significance of global DNA hypomethylation in CRC, curcumin, an anti-cancerous agent, induces DNA methylation in the HCT116, HT29, and RKO cell lines [70].

Another way that alcohol can indirectly affect genetic expression in CRC is by interfering with folate metabolism [10]. Folate is converted into tetrahydrofolate (THF), and then into 5,10-methylenetetrahydrofolate (5,10-MTHF) [10]. At this point, 5,10-MTHF can be used to synthesize DNA by participating in the conversion of dTMP from dUMP via thymidylate synthase (TS) [10]. 5,10-MTHF can also be converted to 5-methyltetrahydrofolate (5-MTHF) by methylenetetrahydrofolate reductase (MTHFR), which is used to produce methionine and, by extension, $S$-adenosylmethionine (SAMe) [10]. It must be noted that the MTHFR polymorphisms C667T and A1298C, as well as the TS polymorphism TS1494del6, have been found in cases with alcohol consumption [10,72]. It has been shown that acetaldehyde can degrade folate [52]. Therefore, by interfering with folate metabolism, both DNA integrity and methylation are affected [10]. Interfering with DNA synthesis can cause double-strand breaks [10]. A reduction in methionine synthesis would lead to global DNA hypomethylation [10]. In the case of CRC, along with a reduction in folate, significantly increased uracil misincorporation and DNA hypomethylation, which were observed in samples of polyps and the surrounding tissues [73].

Alcohol intake can affect other cofactor nutrients, like vitamins B6 and B12, as well [74]. Vitamin B6 is the cofactor of serine hydroxymethyltransferase (SHMT) and cystathionine $\beta$-synthase (CBS) [74]. Vitamin B12 is the cofactor of MTR [74]. Thus, these vitamins are important in both the formation and metabolism of THF, 5,10-MTHF, and methionine [74]. Because chronic alcohol consumption can result in malnutrition and deficiencies in these vitamins, DNA synthesis and methylation would be affected 
as a result [74]. It must be noted, however, that the levels of these vitamins can vary depending on the individual conditions and circumstances [74]. This uncertainty is reflected in the literature, as a cohort study of subjects from the Nurses' Health Study (NHS) did not show a significant correlation between levels of $\mathrm{B}$ vitamins, alcohol intake, and CRC risk with respect to the status of $B R A F$ mutation, a common pathway involved in colon carcinogenesis [75]. However, despite these results, a lack of B vitamins has been widely implicated in colon carcinogenesis overall [10].

In the context of alcohol and colon carcinogenesis, the effects on DNA repair mechanisms are controversial [34,76-79]. Both nucleotide excision repair (NER) and base excision repair (BER) have been proposed to be involved in correcting alcohol-induced DNA damage [79,80]. NER repairs DNA by cleaving parts containing erroneous bases and sequences [79]. This cleaving is accomplished by first recognizing the erroneous bases using a protein complex to unwind the DNA, followed by damage recognition and formation of a preincision complex involving proteins such as XPA, RPA, $\mathrm{XPG}$, and ERCC1. Upon removal of the damaged piece of DNA, repair DNA synthesis is performed by DNA polymerases [81]. BER works by a different mechanism, as it results in the replacement of single, chemically modified nucleotides instead of a sequence [82], first by recognizing the erroneous, chemically modified bases and cleaving them from the DNA strand using glycosylases, such as SMUG1, OGG1, and APE1 [82]. Other than glycosylases that remove chemically-modified bases, there are also enzymes that remove the specific chemical modifications to such bases [77]. For example, MGMT removes alkyl groups from guanine [77].

As previously stated, it is plausible that the alcohol-induced DNA damage and risk of CRC vary based on the capacity of these DNA repair mechanisms [34,76-79]. In a group of Chinese Han colon cancer and control subjects, there seemed to be no association between alcohol consumption and mutation in APE1 [76]. Similarly, in the same group of subjects, insignificance was also found between alcohol consumption and mutation in the genes XRCC1 and OGG1 [76]. Insignificance to alcohol consumption in CRC was observed for mutations in NER proteins like XPA A23G, XPC Lys939Gln, XPD Lys751Gln, and XPD Asp312Asn in a group of 397 Danish colon cancer patients compared to 800 Danish control patients [78]. Because these NER proteins play a major role in CRC, more work needs to be done in order to fully elucidate the effects of alcohol consumption on the range of mutations that they can have $[79,80,83]$. Significant associations have been made between alcohol intake and mutation in MGMT in the presence of the Kras mutation in colon cancer [77].

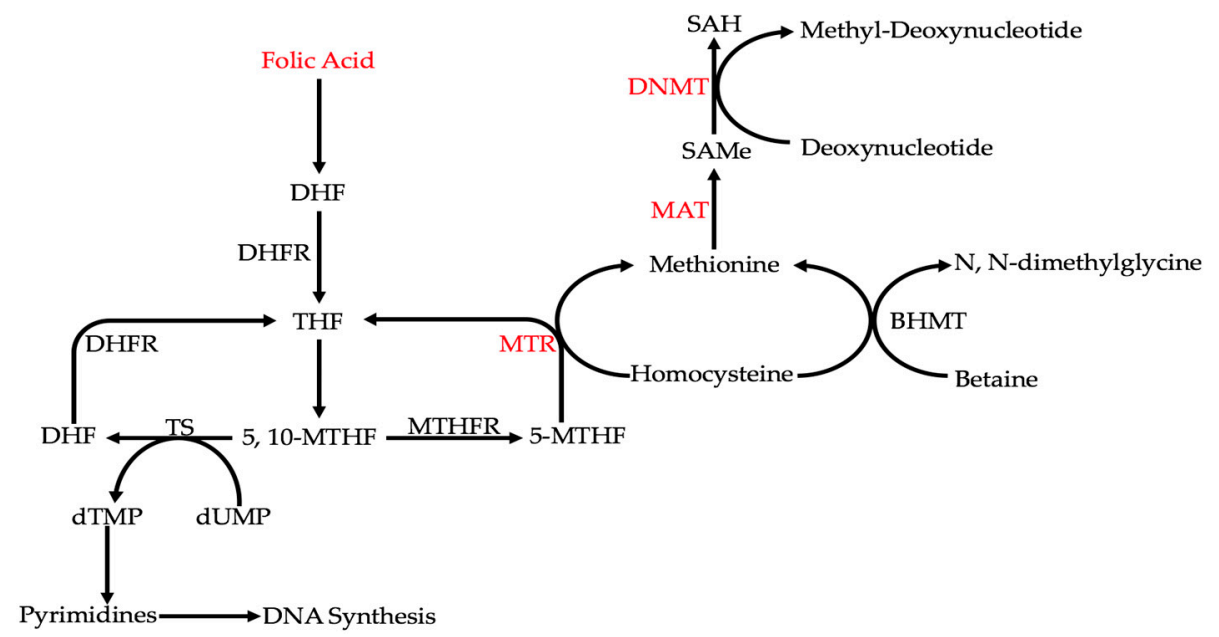

Figure 2. Ethanol indirectly interferes with DNA integrity by affecting key points (labeled in red) or enzymes in folate metabolism. From these key points, DNA synthesis and methylation are hindered. A reduction in folic acid levels decreases all reactions in the above pathway. Reducing methionine synthase (MTR) activity inhibits both DNA synthesis and DNA methylation. Reducing methionine synthase (MAT) and DNA methyltransferase (DNMT) activities inhibits DNA methylation. 


\section{Non-Coding RNAs, Cell Signaling, and Stemness}

\subsection{Non-Coding RNAs and Their Effects}

Ethanol and its metabolites can also affect gene expression in CRC by altering the levels of certain miRNAs (microRNAs) $[9,84]$. By changing the relative amounts of certain miRNAs, ethanol can indirectly influence processes such as lipid metabolism, epithelial to mesenchymal transition (EMT), angiogenesis, and the immune response, affecting carcinogenesis $[9,85,86]$. Some examples of miRNAs that are dysregulated with ethanol are miR-34a, miR-21, and miR-135 [87]. miR-34a has been widely known to be a tumor suppressor, directly regulated by p53 [88]. Like the other miRNAs to be discussed in this review, it has been known to take part in many processes beneficial to the carcinogenic state in the colon [85,88-90]. Normally, miR-34a is a regulator of hepatic glucose, lipid, and drug metabolism [90]. It is typically downregulated in cases of colorectal cancer [87]. Dysregulated miR-34a usually leads to disorders such as obesity, dyslipidemia, and fatty liver disease [91,92]. However, what is interesting about ethanol exposure is that miR-34a increases in an alcohol-fed rat model, which may seem to be preventative against carcinogenesis $[9,93]$. Indeed, miR-34a has been shown to interact with the TGF- $\beta$ /SMAD4 pathway to reduce EMT and increase treatment susceptibility [89]. However, it was shown in a rhesus macaque model that the miR-34a promoter is hypomethylated, leading to increased hepatic miR-34a levels [94]. Such overexpressed miR-34a can, eventually, lead to immune dysregulation and inflammation [92]. Therefore, the unusual dysregulation of miR-34a can either negatively or positively regulate the carcinogenic state through its multiple functions.

Ethanol intake affects other miRNAs, including miR-21, involved in colon carcinogenesis [9,84]. miR-21 is an oncogenic miRNA whose overexpression has been associated with poor prognoses and lower overall survival counts in cases of CRC [95]. It has been associated with multiple cell signaling pathways, leading to oncogenic effects on immunity and stemness [85,96]. Increased miR-21 levels could be mediated via IL-6 signaling and STAT3 activation [85], and in turn, increase NF- $\mathrm{kB}$ and instigate inflammation [85]. miR-21 can further increase a carcinogenic immune state in the tumor microenvironment by modulating IL-10 and prostaglandin E2 (PGE2) production, and decreasing the amount of CD8 + T cells [96]. In addition, miR-21 also promotes cell survival by downregulating the extrinsic apoptotic pathway, as was shown in alcohol-treated human hepatocytes [97]. Besides the IL-6/STAT3 pathway, miR-21 is also upregulated by Ras through increases in AP1 [84]. Increased miR-21 increases $\beta$-catenin and SOX-2 expression, which leads to increased cancer cell stemness [84]. Therefore, by upregulating miR-21, ethanol could increase colon carcinogenesis through increased cancer cell stemness, cell survival, and an altered immune response [84,96,97].

miR-135 is a miRNA that decreases with ethanol exposure [9,98]. It also plays a role in colon carcinogenesis, as miR-135a and miR-135b have been shown to suppress APC, a key pathway commonly involved in CRC [99]. miR-135 has also been shown to be a regulator of focal adhesion kinase (FAK) [100]. FAK is a protein tyrosine kinase that compromises epithelial barrier junctions and encourages cell motility [101,102]. In fact, FAK forms a signaling axis with VEGF, VEGFR2, and AKT (known as the "VEGF-VEGFR2-AKT/FAK signaling axis") to encourage angiogenesis [103]. Therefore, by reducing miR-135, alcohol can not only help develop CRC by upregulating APC- $\beta$-catenin pathway, but may also enhance cell motility and metastasis via increased FAK [101-103].

\subsection{Altered Histone Modifications}

Another epigenetic mechanism through which alcohol can modulate gene expression is via alterations in histone modifications [9]. Alterations in the modifications on histone 3 have been especially reported $[9,104,105]$. It has been shown in ethanol-treated rat hepatocytes that dimethylated H3K4 increases, while dimethylated H3K9 decreases [104]. Similarly, in hepatic samples from ethanol binged rats, phosphorylation on ser-10 and ser-28, as well as $\mathrm{K} 9$ acetylation on H3, were also increased [105]. The H3K9 acetylation was associated with increased phosphorylation of ERK1/2 [105]. Not only that, but H3K9's histone acetyltransferases (HAT), p300 and GCN5, have also been shown to 
be affected by ethanol [106,107]. p300 was shown to increase upon ethanol treatment [106]. GCN5, when knocked down in human hepatoma cells, inhibited ethanol-induced H3K9 acetylation [107]. Finally, ethanol can affect the expression of histone deacetylases (HDACs) [108]. It was shown in an ethanol-binged mouse model that ethanol decreased the expression of HDAC 1, 7, 9, 10, and 11, and increased HDAC 3 expression [108]. SIRT-1, the HDAC that is regulated by miR-34a, decreases with ethanol [9]. Although many of these ethanol-induced modifications have been shown to be involved in the liver damage from alcohol, alterations in HDAC are repeatedly shown in CRC in general, and thus, involvement of HDACs in alcohol-induced colon carcinogenesis is quite possible [9].

\subsection{The Hedgehog Pathway}

The Hedgehog pathway is greatly influenced by ethanol [109]. This pathway has been especially relevant to conditions such as hepatocarcinoma, pancreatitis, and fetal alcohol spectrum defects (FASD) [109-111]. It appears that hedgehog signaling, in the case of hepatocarcinoma, is instigated by ethanol exposure, and that through this signaling, EMT is encouraged [109]. Such an increase in EMT can be connected to hedgehog's role in stemness, as fetal alcohol exposure can lead to birth defects [111]. Alcohol's influence on fetal hedgehog signaling has been shown to be due to deficient sonic hedgehog (Shh) ligand modification by cholesterol [111]. Although the interaction of alcohol with the hedgehog pathway is well defined in certain conditions, more work needs to be performed on its involvement in CRC [109-112]. It can be inferred through more than one study that Shh signaling plays a role in angiogenesis in CRC, as angiogenesis is inhibited when Shh signaling is suppressed [113,114].

\section{The Tumor Microenvironment}

A dysregulated immune response provides a permissive microenvironment that helps tumor growth [13,115]. With regard to CRC, chronic inflammation plays a critical role in CRC development [116]. Chronic alcohol intake can cause mucosal inflammation in the intestine [5]. One mechanism that could induce an inflammatory response in the intestinal tract is via an increased exposure to lipopolysaccharide (LPS) from the intestinal microbiota [5]. The LPS production and exposure can be affected by ethanol, which is shown to induce microbial dysbiosis and bacterial overgrowth $[5,117]$. Ethanol, through multiple mechanisms, is also able to increase the permeability of the intestinal barrier (often referred to as "leaky gut") that allows further LPS penetration and exposure $[62,118]$. Oxidative stress from the CYP2E1 metabolism of ethanol could increase intestinal permeability $[119,120]$. We have shown that, in a Caco-2 cell model, increased oxidative stress leads to increased CREB phosphorylation [119]. This CREB phosphorylation increases hyperpermeability, most likely, through increased ROS production, which can directly affect the barrier's integrity [5]. ROS can also activate the EMT factor, snail [118]. Increased ROS production from acetaldehyde treatment in a Caco-2 cell model led to increased snail phosphorylation which, in turn, resulted in the redistribution of ZO-1, E-cadherin, and $\beta$-catenin [118]. This redistribution decreased the barrier function of the cell monolayer [118]. Our recent data suggests that colonic hyperpermeability from alcohol is at least partly mediated via alcohol's epigenetic effects on Notch1 via altered histone $\mathrm{H} 3$ deacetylation at the Notch1 locus [121]. Besides ROS production, ethanol itself can affect cellular $\beta$-catenin distribution [122,123]. It has been shown in a HCT116 cell model that ethanol inactivates GSK3 $\beta$, leading to an increased nuclear translocation of $\beta$-catenin [122]. This not only could contribute to cancer formation, but also to tumor aggression via production of MCP-1/CCR-2, and induction of cancer stem cell (CSC) metastasis [122]. Increased permeability and exposure to LPS and other microbial byproducts is sensed by immune cells, leading to the expression of pro-inflammatory cytokines like IL-6 and IL-18, as well as further release of ROS, fueling the vicious cycle [5,124]. Barrier dysfunction and increased LPS exposure from alcohol could shift toward a pro-tumorigenic inflammatory response [5,124]. For example, alcohol exposure in mice can lead to an increase in M2b macrophage recruitment [125]. This increase in M2 macrophages is significant, because such an increase has been associated with a poor prognosis in colon cancer patients [126]. 
There are other mechanisms that can contribute to ethanol's increase in intestinal inflammation in cases of CRC [117,119,120,127-129]. Our group showed that chronic alcohol consumption accelerates polyposis in mice; the enhanced polyposis and submucosal invasion in our model was associated with an increased mast cell infiltration in the submucosa [13]. More recently, chronic ethanol feeding in an azoxymethane/dextran sulfate sodium (AOM/DSS) model of CRC in mice was shown to increase cell proliferation, and tumorigenesis [130]. The authors found that alcohol induced release of pro-tumorigenic inflammatory cytokines, such as IL- $1 \alpha$, IL-6, and TNF $\alpha$, was associated with an enhanced immune cell infiltration and colonic inflammation in their model [130]. As intestinal inflammation is one of the main mechanisms via which alcohol promotes CRC, the interaction of alcohol with another factor that could induce intestinal inflammation is plausible.

We showed exacerbation of intestinal inflammation from alcohol by disruption of circadian rhythms, another common habit associated with modern lifestyle [131-133]. Recently, we have reported such an interaction in a CRC model in mouse. In a TS4Cre $\times$ APC ${ }^{\text {low468 }}$ mouse model, we have shown that a diet including alcohol and a weekly $12 \mathrm{~h}$ phase reversal of light-dark cycles resulted in increased polyposis, along with an increased ratio of mMCP6+ mast cells to mMCP2+ mast cells in the intestinal tissue [128]. In the same set of mice, we also found a shift in the microbiota of the alcohol fed, circadian shifted mice where there was a decrease in the Firmicutes/Bacteroidetes ratio, correlating with decreased SCFA production [128]. These results suggest an interaction of circadian disruption and alcohol in CRC, potentially via promotion of a pro-tumorigenic inflammatory milieu.

\section{Conclusions}

The onset of CRC can be heavily influenced by environmental and lifestyle factors [4]. Alcohol consumption, a growing lifestyle habit in developed and some developing countries, appears to be one of the biggest CRC instigators [134-137]. Alcohol's consumption and metabolism can have multiple molecular consequences that can instigate colon carcinogenesis [8-10]. Its oxidative and non-oxidative metabolism, and formation of byproducts, such as ROS and metabolites, can lead to a constellation of genetic, epigenetic, cell signaling, and immune processes (Figure 3) [5,9,10,12,55,65-67]. Interaction of these various mechanisms can affect cancer characteristics like proliferation, angiogenesis, stemness, EMT, oncogenic expression, and altered immunity $[9,89,103,125]$. Still, further work needs to be conducted to elucidate targetable driving mechanisms to prevent alcohol-induced CRC; the identification of such pathways can also help understand how other lifestyle factors interact with alcohol, and with each other, to promote CRC.

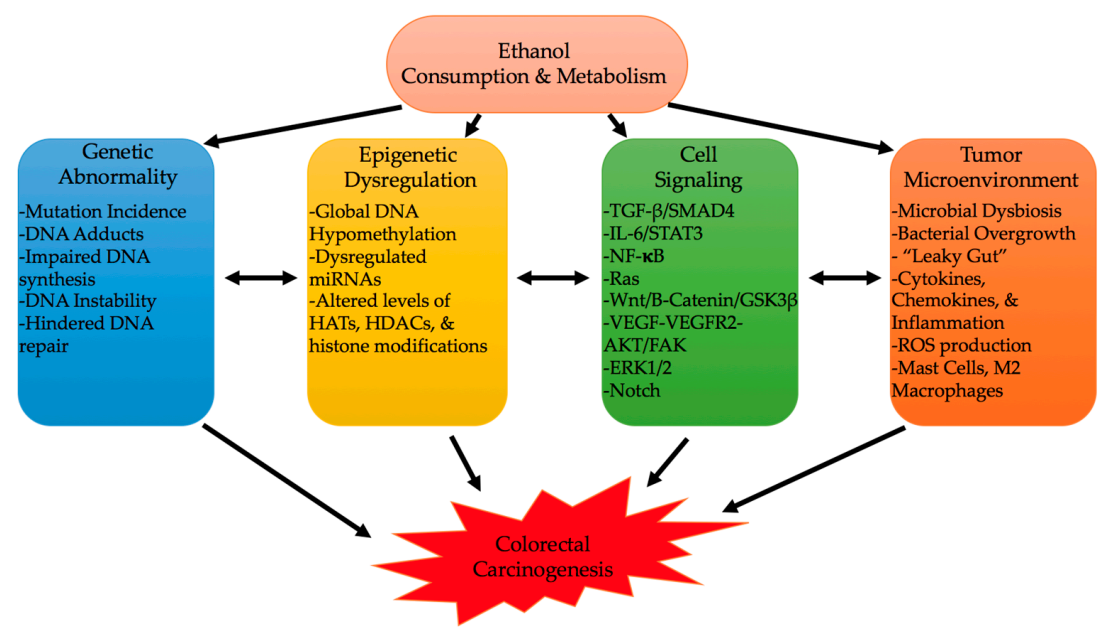

Figure 3. Genetic abnormality, epigenetic dysregulation, cell signaling, and the tumor microenvironment are the hallmark effects that ethanol produces to instigate colorectal carcinogenesis. These hallmark mechanisms interact and lead into each other to further increase the carcinogenic state. 
Acknowledgments: Ali Keshavarzian is supported by NIH-NIAAA R01AA023417; Faraz Bishehsari is supported by Rush Translational Sciences Consortium/Swim across America and thank The Iranian Association of Gastroenterology and Hepatology.

Author Contributions: Marco Rossi drafted and revised the manuscript. Muhammad Jahanzaib Anwar, and Ahmad Usman helped in literature review. Ali Keshavarzian edited the manuscript. Faraz Bishehsari outlined, edited and revised the manuscript. All authors approved the final draft.

Conflicts of Interest: The authors declare no conflicts of interest.

\section{References}

1. Kolligs, F.T. Diagnostics and epidemiology of colorectal cancer. Visc. Med. 2016, 32, 158-164. [CrossRef] [PubMed]

2. Roswall, N.; Weiderpass, E. Alcohol as a risk factor for cancer: Existing evidence in a global perspective. J. Prev. Med. Public Health 2015, 48, 1-9. [CrossRef] [PubMed]

3. Yabroff, K.R.; Warren, J.L.; Schrag, D.; Mariotto, A.; Meekins, A.; Topor, M.; Brown, M.L. Comparison of approaches for estimating incidence costs of care for colorectal cancer patients. Med. Care 2009, 47, S56-S63. [CrossRef] [PubMed]

4. Bishehsari, F.; Mahdavinia, M.; Vacca, M.; Malekzadeh, R.; Mariani-Costantini, R. Epidemiological transition of colorectal cancer in developing countries: Environmental factors, molecular pathways, and opportunities for prevention. World J. Gastroenterol. 2014, 20, 6055-6072. [CrossRef] [PubMed]

5. Bishehsari, F.; Magno, E.; Swanson, G.; Desai, V.; Voigt, R.M.; Forsyth, C.B.; Keshavarzian, A. Alcohol and gut-derived inflammation. Alcohol Res. Curr. Rev. 2017, 38, 163-171.

6. Jemal, A.; Center, M.M.; DeSantis, C.; Ward, E.M. Global patterns of cancer incidence and mortality rates and trends. Cancer Epidemiol. Biomark. Prev. 2010, 19, 1893-1907. [CrossRef] [PubMed]

7. Slattery, M.L.; Potter, J.; Caan, B.; Edwards, S.; Coates, A.; Ma, K.N.; Berry, T.D. Energy balance and colon cancer-Beyond physical activity. Cancer Res. 1997, 57, 75-80. [PubMed]

8. Seitz, H.K.; Becker, P. Alcohol metabolism and cancer risk. Alcohol Res. Health 2007, 30, 38-47. [PubMed]

9. Shukla, S.D.; Lim, R.W. Epigenetic effects of ethanol on the liver and gastrointestinal system. Alcohol Res. Curr. Rev. 2013, 35, 47-55.

10. Varela-Rey, M.; Woodhoo, A.; Martinez-Chantar, M.L.; Mato, J.M.; Lu, S.C. Alcohol, DNA methylation, and cancer. Alcohol Res. Curr. Rev. 2013, 35, 25-35.

11. Dinis-Oliveira, R.J. Oxidative and non-oxidative metabolomics of ethanol. Curr. Drug Metab. 2016, 17, 327-335. [CrossRef] [PubMed]

12. Haas, S.L.; Ye, W.; Lohr, J.M. Alcohol consumption and digestive tract cancer. Curr. Opin. Clin. Nutr. Metab. Care 2012, 15, 457-467. [CrossRef] [PubMed]

13. Wimberly, A.L.; Forsyth, C.B.; Khan, M.W.; Pemberton, A.; Khazaie, K.; Keshavarzian, A. Ethanol-induced mast cell-mediated inflammation leads to increased susceptibility of intestinal tumorigenesis in the APC delta468 min mouse model of colon cancer. Alcohol. Clin. Exp. Res. 2013, 37, E199-E208. [CrossRef] [PubMed]

14. Cai, S.; Li, Y.; Ding, Y.; Chen, K.; Jin, M. Alcohol drinking and the risk of colorectal cancer death: A meta-analysis. Eur. J. Cancer Prev. 2014, 23, 532-539. [CrossRef] [PubMed]

15. Haggar, F.A.; Boushey, R.P. Colorectal cancer epidemiology: Incidence, mortality, survival, and risk factors. Clin. Colon Rectal Surg. 2009, 22, 191-197. [CrossRef] [PubMed]

16. Fedirko, V.; Tramacere, I.; Bagnardi, V.; Rota, M.; Scotti, L.; Islami, F.; Negri, E.; Straif, K.; Romieu, I.; La Vecchia, C.; et al. Alcohol drinking and colorectal cancer risk: An overall and dose-response meta-analysis of published studies. Ann. Oncol. 2011, 22, 1958-1972. [CrossRef] [PubMed]

17. Ibanez-Sanz, G.; Diez-Villanueva, A.; Alonso, M.H.; Rodriguez-Moranta, F.; Perez-Gomez, B.; Bustamante, M.; Martin, V.; Llorca, J.; Amiano, P.; Ardanaz, E.; et al. Risk model for colorectal cancer in Spanish population using environmental and genetic factors: Results from the MCC-Spain study. Sci. Rep. 2017, 7, 43263. [CrossRef] [PubMed]

18. Klarich, D.S.; Brasser, S.M.; Hong, M.Y. Moderate alcohol consumption and colorectal cancer risk. Alcohol. Clin. Exp. Res. 2015, 39, 1280-1291. [CrossRef] [PubMed] 
19. Yun, J.W.; Son, M.J.; Abdelmegeed, M.A.; Banerjee, A.; Morgan, T.R.; Yoo, S.H.; Song, B.J. Binge alcohol promotes hypoxic liver injury through a CYP2E1-HIF-1alpha-dependent apoptosis pathway in mice and humans. Free Radic. Biol. Med. 2014, 77, 183-194. [CrossRef] [PubMed]

20. Walter, V.; Jansen, L.; Ulrich, A.; Roth, W.; Blaker, H.; Chang-Claude, J.; Hoffmeister, M.; Brenner, H. Alcohol consumption and survival of colorectal cancer patients: A population-based study from germany. Am. J. Clin. Nutr. 2016, 103, 1497-1506. [CrossRef] [PubMed]

21. Yang, B.; Gapstur, S.M.; Newton, C.C.; Jacobs, E.J.; Campbell, P.T. Alcohol intake and mortality among survivors of colorectal cancer: The cancer prevention study II nutrition cohort. Cancer 2017, 123, 2006-2013. [CrossRef] [PubMed]

22. Pelser, C.; Arem, H.; Pfeiffer, R.M.; Elena, J.W.; Alfano, C.M.; Hollenbeck, A.R.; Park, Y. Prediagnostic lifestyle factors and survival after colon and rectal cancer diagnosis in the national institutes of health (NIH)-AARP diet and health study. Cancer 2014, 120, 1540-1547. [CrossRef] [PubMed]

23. Ahrendt, S.A.; Hu, Y.; Buta, M.; McDermott, M.P.; Benoit, N.; Yang, S.C.; Wu, L.; Sidransky, D. P53 mutations and survival in stage I non-small-cell lung cancer: Results of a prospective study. J. Natl. Cancer Inst. 2003, 95, 961-970. [CrossRef] [PubMed]

24. Wu, W.J.; Pruett, S.B. Ethanol decreases host resistance to pulmonary metastases in a mouse model: Role of natural killer cells and the ethanol-induced stress response. Int. J. Cancer 1999, 82, 886-892. [CrossRef]

25. Paull, D.E.; Updyke, G.M.; Baumann, M.A.; Chin, H.W.; Little, A.G.; Adebonojo, S.A. Alcohol abuse predicts progression of disease and death in patients with lung cancer. Ann. Thorac. Surg. 2005, 80, 1033-1039. [CrossRef] [PubMed]

26. Cho, E.; Lee, J.E.; Rimm, E.B.; Fuchs, C.S.; Giovannucci, E.L. Alcohol consumption and the risk of colon cancer by family history of colorectal cancer. Am. J. Clin. Nutr. 2012, 95, 413-419. [CrossRef] [PubMed]

27. Zhao, J.; Zhu, Y.; Wang, P.P.; West, R.; Buehler, S.; Sun, Z.; Squires, J.; Roebothan, B.; McLaughlin, J.R.; Campbell, P.T.; et al. Interaction between alcohol drinking and obesity in relation to colorectal cancer risk: A case-control study in Newfoundland and Labrador, Canada. BMC Public Health 2012, 12, 94. [CrossRef] [PubMed]

28. Owusu, D.; Quinn, M.; Wang, K.S. Alcohol consumption, depression, insomnia and colorectal cancer screening: Racial differences. Int. J. High Risk Behav. Addict. 2015, 4, e23424. [CrossRef]

29. Gonzales, M.; Nelson, H.; Rhyne, R.L.; Stone, S.N.; Hoffman, R.M. Surveillance of colorectal cancer screening in New Mexico hispanics and non-hispanic whites. J. Community Health 2012, 37, 1279-1288. [CrossRef] [PubMed]

30. Fagunwa, I.O.; Loughrey, M.B.; Coleman, H.G. Alcohol, smoking and the risk of premalignant and malignant colorectal neoplasms. Best Pract. Res. Clin. Gastroenterol. 2017, 31, 561-568. [CrossRef] [PubMed]

31. Gao, C.M.; Takezaki, T.; Wu, J.Z.; Zhang, X.M.; Cao, H.X.; Ding, J.H.; Liu, Y.T.; Li, S.P.; Cao, J.; Matsuo, K.; et al. Polymorphisms of alcohol dehydrogenase 2 and aldehyde dehydrogenase 2 and colorectal cancer risk in Chinese males. World J. Gastroenterol. 2008, 14, 5078-5083. [CrossRef] [PubMed]

32. Peng, G.S.; Chen, Y.C.; Tsao, T.P.; Wang, M.F.; Yin, S.J. Pharmacokinetic and pharmacodynamic basis for partial protection against alcoholism in Asians, heterozygous for the variant ALDH2*2 gene allele. Pharmacogenet. Genom. 2007, 17, 845-855. [CrossRef] [PubMed]

33. Guo, X.F.; Wang, J.; Yu, S.J.; Song, J.; Ji, M.Y.; Zhang, J.X.; Cao, Z.; Wang, J.; Dong, W.G. Meta-analysis of the $\mathrm{ADH} 1 \mathrm{~B}$ and ALDH2 polymorphisms and the risk of colorectal cancer in East Asians. Intern. Med. 2013, 52, 2693-2699. [CrossRef] [PubMed]

34. Chen, C.; Wang, L.; Liao, Q.; Xu, L.; Huang, Y.; Zhang, C.; Ye, H.; Xu, X.; Ye, M.; Duan, S. Association between six genetic polymorphisms and colorectal cancer: A meta-analysis. Genet. Test. Mol. Biomark. 2014, 18, 187-195. [CrossRef] [PubMed]

35. Chang, J.S.; Hsiao, J.R.; Chen, C.H. ALDH2 polymorphism and alcohol-related cancers in Asians: A public health perspective. J. Biomed. Sci. 2017, 24, 19. [CrossRef] [PubMed]

36. Bongaerts, B.W.; van den Brandt, P.A.; Goldbohm, R.A.; de Goeij, A.F.; Weijenberg, M.P. Alcohol consumption, type of alcoholic beverage and risk of colorectal cancer at specific subsites. Int. J. Cancer 2008, 123, 2411-2417. [CrossRef] [PubMed] 
37. Ferrari, P.; Jenab, M.; Norat, T.; Moskal, A.; Slimani, N.; Olsen, A.; Tjonneland, A.; Overvad, K.; Jensen, M.K.; Boutron-Ruault, M.C.; et al. Lifetime and baseline alcohol intake and risk of colon and rectal cancers in the European prospective investigation into cancer and nutrition (EPIC). Int. J. Cancer 2007, 121, 2065-2072. [CrossRef] [PubMed]

38. Baron, J.A.; Sandler, R.S.; Haile, R.W.; Mandel, J.S.; Mott, L.A.; Greenberg, E.R. Folate intake, alcohol consumption, cigarette smoking, and risk of colorectal adenomas. J. Natl. Cancer Inst. 1998, 90, 57-62. [CrossRef] [PubMed]

39. Giacosa, A.; Frascio, F.; Munizzi, F. Epidemiology of colorectal polyps. Tech. Coloproctol. 2004, 8, s243-s247. [CrossRef] [PubMed]

40. Honjo, S.; Kono, S.; Shinchi, K.; Imanishi, K.; Hirohata, T. Cigarette smoking, alcohol use and adenomatous polyps of the sigmoid colon. Jpn. J. Cancer Res. Gann 1992, 83, 806-811. [CrossRef] [PubMed]

41. Cope, G.F.; Wyatt, J.I.; Pinder, I.F.; Lee, P.N.; Heatley, R.V.; Kelleher, J. Alcohol consumption in patients with colorectal adenomatous polyps. Gut 1991, 32, 70-72. [CrossRef] [PubMed]

42. Zhu, J.Z.; Wang, Y.M.; Zhou, Q.Y.; Zhu, K.F.; Yu, C.H.; Li, Y.M. Systematic review with meta-analysis: Alcohol consumption and the risk of colorectal adenoma. Aliment. Pharmacol. Ther. 2014, 40, 325-337. [CrossRef] [PubMed]

43. Bailie, L.; Loughrey, M.B.; Coleman, H.G. Lifestyle risk factors for serrated colorectal polyps: A systematic review and meta-analysis. Gastroenterology 2017, 152, 92-104. [CrossRef] [PubMed]

44. Makkar, R.; Pai, R.K.; Burke, C.A. Sessile serrated polyps: Cancer risk and appropriate surveillance. Clevel. Clin. J. Med. 2012, 79, 865-871. [CrossRef] [PubMed]

45. Bardou, M.; Montembault, S.; Giraud, V.; Balian, A.; Borotto, E.; Houdayer, C.; Capron, F.; Chaput, J.C.; Naveau, S. Excessive alcohol consumption favours high risk polyp or colorectal cancer occurrence among patients with adenomas: A case control study. Gut 2002, 50, 38-42. [CrossRef] [PubMed]

46. Ma, A.T.; Therrien, A.; Giard, J.M.; von Renteln, D.; Bouin, M. Alcoholic liver disease is a strong predictor of colorectal polyps in liver transplant recipients. Endosc. Int. Open 2017, 5, E918-E923. [CrossRef] [PubMed]

47. Boutron, M.C.; Faivre, J.; Dop, M.C.; Quipourt, V.; Senesse, P. Tobacco, alcohol, and colorectal tumors: A multistep process. Am. J. Epidemiol. 1995, 141, 1038-1046. [PubMed]

48. Steinmetz, J.; Spyckerelle, Y.; Gueguen, R.; Dupre, C. Alcohol, tobacco and colorectal adenomas and cancer. Case-control study in a population with positive fecal occult blood tests. Presse Med. (Paris Fr. 1983) 2007, 36, 1174-1182. [CrossRef] [PubMed]

49. Hassan, C.; Pickhardt, P.J.; Marmo, R.; Choi, J.R. Impact of lifestyle factors on colorectal polyp detection in the screening setting. Dis. Colon Rectum 2010, 53, 1328-1333. [CrossRef] [PubMed]

50. Setshedi, M.; Wands, J.R.; Monte, S.M. Acetaldehyde adducts in alcoholic liver disease. Oxid. Med. Cell. Longev. 2010, 3, 178-185. [CrossRef] [PubMed]

51. Tsuruya, A.; Kuwahara, A.; Saito, Y.; Yamaguchi, H.; Tsubo, T.; Suga, S.; Inai, M.; Aoki, Y.; Takahashi, S.; Tsutsumi, E.; et al. Ecophysiological consequences of alcoholism on human gut microbiota: Implications for ethanol-related pathogenesis of colon cancer. Sci. Rep. 2016, 6, 27923. [CrossRef] [PubMed]

52. Na, H.K.; Lee, J.Y. Molecular basis of alcohol-related gastric and colon cancer. Int. J. Mol. Sci. 2017, 18, 1116.

53. Seitz, H.K.; Stickel, F. Molecular mechanisms of alcohol-mediated carcinogenesis. Nat. Rev. Cancer 2007, 7, 599-612. [CrossRef] [PubMed]

54. Seitz, H.K.; Stickel, F. Acetaldehyde as an underestimated risk factor for cancer development: Role of genetics in ethanol metabolism. Genes Nutr. 2010, 5, 121-128. [CrossRef] [PubMed]

55. Kruman, I.I.; Henderson, G.I.; Bergeson, S.E. DNA damage and neurotoxicity of chronic alcohol abuse. Exp. Biol. Med. 2012, 237, 740-747. [CrossRef] [PubMed]

56. Heier, C.; Xie, H.; Zimmermann, R. Nonoxidative ethanol metabolism in humans-from biomarkers to bioactive lipids. IUBMB Life 2016, 68, 916-923. [CrossRef] [PubMed]

57. Chiang, C.P.; Jao, S.W.; Lee, S.P.; Chen, P.C.; Chung, C.C.; Lee, S.L.; Nieh, S.; Yin, S.J. Expression pattern, ethanol-metabolizing activities, and cellular localization of alcohol and aldehyde dehydrogenases in human large bowel: Association of the functional polymorphisms of adh and aldh genes with hemorrhoids and colorectal cancer. Alcohol 2012, 46, 37-49. [CrossRef] [PubMed]

58. Tillonen, J.; Kaihovaara, P.; Jousimies-Somer, H.; Heine, R.; Salaspuro, M. Role of catalase in in vitro acetaldehyde formation by human colonic contents. Alcohol. Clin. Exp. Res. 1998, 22, 1113-1119. [CrossRef] [PubMed] 
59. Tsuruya, A.; Kuwahara, A.; Saito, Y.; Yamaguchi, H.; Tenma, N.; Inai, M.; Takahashi, S.; Tsutsumi, E.; Suwa, Y.; Totsuka, Y.; et al. Major anaerobic bacteria responsible for the production of carcinogenic acetaldehyde from ethanol in the colon and rectum. Alcohol Alcohol. 2016, 51, 395-401. [CrossRef] [PubMed]

60. Homann, N.; Tillonen, J.; Salaspuro, M. Microbially produced acetaldehyde from ethanol may increase the risk of colon cancer via folate deficiency. Int. J. Cancer 2000, 86, 169-173. [CrossRef]

61. Visapaa, J.P.; Tillonen, J.; Salaspuro, M. Microbes and mucosa in the regulation of intracolonic acetaldehyde concentration during ethanol challenge. Alcohol Alcohol. 2002, 37, 322-326. [CrossRef] [PubMed]

62. Elamin, E.E.; Masclee, A.A.; Dekker, J.; Jonkers, D.M. Ethanol metabolism and its effects on the intestinal epithelial barrier. Nutr. Rev. 2013, 71, 483-499. [CrossRef] [PubMed]

63. Nosova, T.; Jokelainen, K.; Kaihovaara, P.; Heine, R.; Jousimies-Somer, H.; Salaspuro, M. Characteristics of aldehyde dehydrogenases of certain aerobic bacteria representing human colonic flora. Alcohol Alcohol. 1998, 33, 273-280. [CrossRef] [PubMed]

64. Salaspuro, M. Microbial metabolism of ethanol and acetaldehyde and clinical consequences. Addict. Biol. 1997, 2, 35-46. [CrossRef] [PubMed]

65. Moon, J.W.; Lee, S.K.; Lee, Y.W.; Lee, J.O.; Kim, N.; Lee, H.J.; Seo, J.S.; Kim, J.; Kim, H.S.; Park, S.H. Alcohol induces cell proliferation via hypermethylation of adhfe1 in colorectal cancer cells. BMC Cancer 2014, 14, 377. [CrossRef] [PubMed]

66. Hutchison, J.; Cohen, Z.; Onyeagucha, B.C.; Funk, J.; Nelson, M.A. How micrornas influence both hereditary and inflammatory-mediated colon cancers. Cancer Genet. 2013, 206, 309-316. [CrossRef] [PubMed]

67. Yang, Y.; Zhao, L.; Lei, L.; Lau, W.B.; Lau, B.; Yang, Q.; Le, X.; Yang, H.; Wang, C.; Luo, Z.; et al. Lncrnas: The bridge linking rna and colorectal cancer. Oncotarget 2017, 8, 12517-12532. [CrossRef] [PubMed]

68. Bongaerts, B.W.; de Goeij, A.F.; de Vogel, S.; van den Brandt, P.A.; Goldbohm, R.A.; Weijenberg, M.P. Alcohol consumption and distinct molecular pathways to colorectal cancer. Br. J. Nutr. 2007, 97, 430-434. [CrossRef] [PubMed]

69. Linhart, K.; Bartsch, H.; Seitz, H.K. The role of reactive oxygen species (ROS) and cytochrome P-450 2E1 in the generation of carcinogenic etheno-DNA adducts. Redox Biol. 2014, 3, 56-62. [CrossRef] [PubMed]

70. Link, A.; Balaguer, F.; Shen, Y.; Lozano, J.J.; Leung, H.C.; Boland, C.R.; Goel, A. Curcumin modulates DNA methylation in colorectal cancer cells. PLoS ONE 2013, 8, e57709. [CrossRef] [PubMed]

71. Hur, K.; Cejas, P.; Feliu, J.; Moreno-Rubio, J.; Burgos, E.; Boland, C.R.; Goel, A. Hypomethylation of long interspersed nuclear element-1 (LINE-1) leads to activation of proto-oncogenes in human colorectal cancer metastasis. Gut 2014, 63, 635-646. [CrossRef] [PubMed]

72. Eussen, S.J.; Vollset, S.E.; Igland, J.; Meyer, K.; Fredriksen, A.; Ueland, P.M.; Jenab, M.; Slimani, N.; Boffetta, P.; Overvad, K.; et al. Plasma folate, related genetic variants, and colorectal cancer risk in EPIC. Cancer Epidemiol. Biomark. Prev. 2010, 19, 1328-1340. [CrossRef] [PubMed]

73. McGlynn, A.P.; Wasson, G.R.; O’Reilly, S.L.; McNulty, H.; Downes, C.S.; Chang, C.K.; Hoey, L.; Molloy, A.M.; Ward, M.; Strain, J.J.; et al. Low colonocyte folate is associated with uracil misincorporation and global DNA hypomethylation in human colorectum. J. Nutr. 2013, 143, 27-33. [CrossRef] [PubMed]

74. Hiraoka, M.; Kagawa, Y. Genetic polymorphisms and folate status. Congenit. Anom. 2017, 57, $142-149$. [CrossRef] [PubMed]

75. Schernhammer, E.S.; Giovannucci, E.; Baba, Y.; Fuchs, C.S.; Ogino, S. B vitamins, methionine and alcohol intake and risk of colon cancer in relation to BRAF mutation and $\mathrm{CpG}$ island methylator phenotype (CIMP). PLoS ONE 2011, 6, e21102. [CrossRef] [PubMed]

76. Zhang, S.H.; Wang, L.A.; Li, Z.; Peng, Y.; Cun, Y.P.; Dai, N.; Cheng, Y.; Xiao, H.; Xiong, Y.L.; Wang, D. APE1 polymorphisms are associated with colorectal cancer susceptibility in Chinese Hans. World J. Gastroenterol. 2014, 20, 8700-8708. [CrossRef] [PubMed]

77. Sinha, R.; Hussain, S.; Mehrotra, R.; Kumar, R.S.; Kumar, K.; Pande, P.; Doval, D.C.; Basir, S.F.; Bharadwaj, M. Kras gene mutation and RASSF1A, FHIT and MGMT gene promoter hypermethylation: Indicators of tumor staging and metastasis in adenocarcinomatous sporadic colorectal cancer in Indian population. PLoS ONE 2013, 8, e60142. [CrossRef] [PubMed]

78. Hansen, R.D.; Sorensen, M.; Tjonneland, A.; Overvad, K.; Wallin, H.; Raaschou-Nielsen, O.; Vogel, U. XPA A23G, XPC Lys939Gln, XPD Lys751Gln and XPD Asp312Asn polymorphisms, interactions with smoking, alcohol and dietary factors, and risk of colorectal cancer. Mutat. Res. 2007, 619, 68-80. [CrossRef] [PubMed] 
79. Monzo, M.; Moreno, I.; Navarro, A.; Ibeas, R.; Artells, R.; Gel, B.; Martinez, F.; Moreno, J.; Hernandez, R.; Navarro-Vigo, M. Single nucleotide polymorphisms in nucleotide excision repair genes XPA, XPD, XPG and ERCC1 in advanced colorectal cancer patients treated with first-line oxaliplatin/fluoropyrimidine. Oncology 2007, 72, 364-370. [CrossRef] [PubMed]

80. Gil, J.; Ramsey, D.; Stembalska, A.; Karpinski, P.; Pesz, K.A.; Laczmanska, I.; Leszczynski, P.; Grzebieniak, Z.; Sasiadek, M.M. The C/A polymorphism in intron 11 of the XPC gene plays a crucial role in the modulation of an individual's susceptibility to sporadic colorectal cancer. Mol. Biol. Rep. 2012, 39, 527-534. [CrossRef] [PubMed]

81. Scharer, O.D. Nucleotide excision repair in eukaryotes. Cold Spring Harb. Perspect. Biol. 2013, 5, a012609. [CrossRef] [PubMed]

82. Brenerman, B.M.; Illuzzi, J.L.; Wilson, D.M., 3rd. Base excision repair capacity in informing healthspan. Carcinogenesis 2014, 35, 2643-2652. [CrossRef] [PubMed]

83. Slyskova, J.; Naccarati, A.; Pardini, B.; Polakova, V.; Vodickova, L.; Smerhovsky, Z.; Levy, M.; Lipska, L.; Liska, V.; Vodicka, P. Differences in nucleotide excision repair capacity between newly diagnosed colorectal cancer patients and healthy controls. Mutagenesis 2012, 27, 225-232. [CrossRef] [PubMed]

84. Yu, Y.; Nangia-Makker, P.; Farhana, L.; Rajendra, S.G.; Levi, E.; Majumdar, A.P. miR-21 and miR-145 cooperation in regulation of colon cancer stem cells. Mol. Cancer 2015, 14, 98. [CrossRef] [PubMed]

85. Chi, Y.; Zhou, D. Micrornas in colorectal carcinoma-From pathogenesis to therapy. J. Exp. Clin. Cancer Res. 2016, 35, 43. [CrossRef] [PubMed]

86. Lamichhane, T.N.; Leung, C.A.; Douti, L.Y.; Jay, S.M. Ethanol induces enhanced vascularization bioactivity of endothelial cell-derived extracellular vesicles via regulation of microRNAs and long non-coding RNAs. Sci. Rep. 2017, 7, 13794. [CrossRef] [PubMed]

87. Almeida, A.L.; Bernardes, M.V.; Feitosa, M.R.; Peria, F.M.; Tirapelli, D.P.; Rocha, J.J.; Feres, O. Serological under expression of microRNA-21, microRNA-34a and microRNA-126 in colorectal cancer. Acta Cir. Bras. 2016, 31, 13-18. [CrossRef] [PubMed]

88. Wang, L.; Bu, P.; Ai, Y.; Srinivasan, T.; Chen, H.J.; Xiang, K.; Lipkin, S.M.; Shen, X. A long non-coding RNA targets microRNA miR-34a to regulate colon cancer stem cell asymmetric division. eLife 2016, 5, e14620. [CrossRef] [PubMed]

89. Sun, C.; Wang, F.J.; Zhang, H.G.; Xu, X.Z.; Jia, R.C.; Yao, L.; Qiao, P.F. miR-34a mediates oxaliplatin resistance of colorectal cancer cells by inhibiting macroautophagy via transforming growth factor-beta/smad4 pathway. World J. Gastroenterol. 2017, 23, 1816-1827. [CrossRef] [PubMed]

90. Krattinger, R.; Bostrom, A.; Lee, S.M.L.; Thasler, W.E.; Schioth, H.B.; Kullak-Ublick, G.A.; Mwinyi, J. Chenodeoxycholic acid significantly impacts the expression of miRNAs and genes involved in lipid, bile acid and drug metabolism in human hepatocytes. Life Sci. 2016, 156, 47-56. [CrossRef] [PubMed]

91. Lavery, C.A.; Kurowska-Stolarska, M.; Holmes, W.M.; Donnelly, I.; Caslake, M.; Collier, A.; Baker, A.H.; Miller, A.M. miR-34a $\mathrm{a}^{(-/-)}$mice are susceptible to diet-induced obesity. Obesity 2016, 24, 1741-1751. [CrossRef] [PubMed]

92. Salvoza, N.C.; Klinzing, D.C.; Gopez-Cervantes, J.; Baclig, M.O. Association of circulating serum miR-34a and miR-122 with dyslipidemia among patients with non-alcoholic fatty liver disease. PLoS ONE 2016, 11, e0153497. [CrossRef] [PubMed]

93. Dippold, R.P.; Vadigepalli, R.; Gonye, G.E.; Patra, B.; Hoek, J.B. Chronic ethanol feeding alters miRNA expression dynamics during liver regeneration. Alcohol. Clin. Exp. Res. 2013, 37, E59-E69. [CrossRef] [PubMed]

94. Barr, T.; Girke, T.; Sureshchandra, S.; Nguyen, C.; Grant, K.; Messaoudi, I. Alcohol consumption modulates host defense in rhesus macaques by altering gene expression in circulating leukocytes. J. Immunol. 2016, 196, 182-195. [CrossRef] [PubMed]

95. Chen, Z.; Liu, H.; Jin, W.; Ding, Z.; Zheng, S.; Yu, Y. Tissue microRNA-21 expression predicted recurrence and poor survival in patients with colorectal cancer-A meta-analysis. Onco Targets Ther. 2016, 9, 2615-2624. [PubMed]

96. Mima, K.; Nishihara, R.; Nowak, J.A.; Kim, S.A.; Song, M.; Inamura, K.; Sukawa, Y.; Masuda, A.; Yang, J.; Dou, R.; et al. MicroRNA miR21 and T cells in colorectal cancer. Cancer Immunol. Res. 2016, 4, 33-40. [CrossRef] [PubMed] 
97. Francis, H.; McDaniel, K.; Han, Y.; Liu, X.; Kennedy, L.; Yang, F.; McCarra, J.; Zhou, T.; Glaser, S.; Venter, J.; et al. Regulation of the extrinsic apoptotic pathway by microRNA-21 in alcoholic liver injury. J. Biol. Chem. 2014, 289, 27526-27539. [CrossRef] [PubMed]

98. Yeligar, S.; Tsukamoto, H.; Kalra, V.K. Ethanol-induced expression of ET-1 and ET-BR in liver sinusoidal endothelial cells and human endothelial cells involves hypoxia-inducible factor-1alpha and microRNA-199. J. Immunol. 2009, 183, 5232-5243. [CrossRef] [PubMed]

99. Nagel, R.; le Sage, C.; Diosdado, B.; van der Waal, M.; Oude Vrielink, J.A.; Bolijn, A.; Meijer, G.A.; Agami, R. Regulation of the adenomatous polyposis coli gene by the miR-135 family in colorectal cancer. Cancer Res. 2008, 68, 5795-5802. [CrossRef] [PubMed]

100. Golubovskaya, V.M.; Sumbler, B.; Ho, B.; Yemma, M.; Cance, W.G. miR-138 and miR-135 directly target focal adhesion kinase, inhibit cell invasion, and increase sensitivity to chemotherapy in cancer cells. Anti-Cancer Agents Med. Chem. 2014, 14, 18-28. [CrossRef]

101. Ma, Y.; Semba, S.; Khan, R.I.; Bochimoto, H.; Watanabe, T.; Fujiya, M.; Kohgo, Y.; Liu, Y.; Taniguchi, T. Focal adhesion kinase regulates intestinal epithelial barrier function via redistribution of tight junction. Biochim. Biophys. Acta 2013, 1832, 151-159. [CrossRef] [PubMed]

102. Zhuang, Y.; Peng, H.; Mastej, V.; Chen, W. Microrna regulation of endothelial junction proteins and clinical consequence. Mediat. Inflamm. 2016, 2016, 5078627. [CrossRef] [PubMed]

103. Bi, Y.L.; Mi, P.Y.; Zhao, S.J.; Pan, H.M.; Li, H.J.; Liu, F.; Shao, L.R.; Zhang, H.F.; Zhang, P.; Jiang, S.L. Salinomycin exhibits anti-angiogenic activity against human glioma in vitro and in vivo by suppressing the VEGF-VEGFR2-AKT/FAK signaling axis. Int. J. Mol. Med. 2017, 39, 1255-1261. [CrossRef] [PubMed]

104. Pal-Bhadra, M.; Bhadra, U.; Jackson, D.E.; Mamatha, L.; Park, P.H.; Shukla, S.D. Distinct methylation patterns in histone $\mathrm{H} 3$ at Lys-4 and Lys-9 correlate with up- \& down-regulation of genes by ethanol in hepatocytes. Life Sci. 2007, 81, 979-987. [PubMed]

105. Aroor, A.R.; James, T.T.; Jackson, D.E.; Shukla, S.D. Differential changes in map kinases, histone modifications, and liver injury in rats acutely treated with ethanol. Alcohol. Clin. Exp. Res. 2010, 34, 1543-1551. [CrossRef] [PubMed]

106. Bardag-Gorce, F.; French, B.A.; Joyce, M.; Baires, M.; Montgomery, R.O.; Li, J.; French, S. Histone acetyltransferase p300 modulates gene expression in an epigenetic manner at high blood alcohol levels. Exp. Mol. Pathol. 2007, 82, 197-202. [CrossRef] [PubMed]

107. Choudhury, M.; Pandey, R.S.; Clemens, D.L.; Davis, J.W.; Lim, R.W.; Shukla, S.D. Knock down of GCN5 histone acetyltransferase by siRNA decreases ethanol-induced histone acetylation and affects differential expression of genes in human hepatoma cells. Alcohol 2011, 45, 311-324. [CrossRef] [PubMed]

108. Kirpich, I.; Ghare, S.; Zhang, J.; Gobejishvili, L.; Kharebava, G.; Barve, S.J.; Barker, D.; Moghe, A.; McClain, C.J.; Barve, S. Binge alcohol-induced microvesicular liver steatosis and injury are associated with down-regulation of hepatic Hdac 1, 7, 9, 10, 11 and up-regulation of Hdac 3. Alcohol. Clin. Exp. Res. 2012, 36, 1578-1586. [CrossRef] [PubMed]

109. Chan, I.S.; Guy, C.D.; Machado, M.V.; Wank, A.; Kadiyala, V.; Michelotti, G.; Choi, S.; Swiderska-Syn, M.; Karaca, G.; Pereira, T.A.; et al. Alcohol activates the hedgehog pathway and induces related procarcinogenic processes in the alcohol-preferring rat model of hepatocarcinogenesis. Alcohol. Clin. Exp. Res. 2014, 38, 787-800. [CrossRef] [PubMed]

110. Wang, L.W.; Lin, H.; Lu, Y.; Xia, W.; Gao, J.; Li, Z.S. Sonic hedgehog expression in a rat model of chronic pancreatitis. World J. Gastroenterol. 2014, 20, 4712-4717. [CrossRef] [PubMed]

111. Li, Y.X.; Yang, H.T.; Zdanowicz, M.; Sicklick, J.K.; Qi, Y.; Camp, T.J.; Diehl, A.M. Fetal alcohol exposure impairs hedgehog cholesterol modification and signaling. Lab. Invest. 2007, 87, 231-240. [CrossRef] [PubMed]

112. Latchoumycandane, C.; Hanouneh, M.; Nagy, L.E.; McIntyre, T.M. Inflammatory paf receptor signaling initiates hedgehog signaling and kidney fibrogenesis during ethanol consumption. PLOS ONE 2015, 10, e0145691. [CrossRef] [PubMed]

113. Lin, J.; Wei, L.; Shen, A.; Cai, Q.; Xu, W.; Li, H.; Zhan, Y.; Hong, Z.; Peng, J. Hedyotis diffusa willd extract suppresses sonic hedgehog signaling leading to the inhibition of colorectal cancer angiogenesis. Int. J. Oncol. 2013, 42, 651-656. [CrossRef] [PubMed]

114. Wei, L.; Lin, J.; Xu, W.; Cai, Q.; Shen, A.; Hong, Z.; Peng, J. Scutellaria barbata D. Don inhibits tumor angiogenesis via suppression of hedgehog pathway in a mouse model of colorectal cancer. Int. J. Mol. Sci. 2012, 13, 9419-9430. [CrossRef] [PubMed] 
115. Nicholas, N.S.; Apollonio, B.; Ramsay, A.G. Tumor microenvironment (TME)-driven immune suppression in B cell malignancy. Biochim. Biophys. Acta 2016, 1863, 471-482. [CrossRef] [PubMed]

116. Moossavi, S.; Bishehsari, F. Inflammation in sporadic colorectal cancer. Arch. Iran. Med. 2012, 15, $166-170$. [PubMed]

117. Engen, P.A.; Green, S.J.; Voigt, R.M.; Forsyth, C.B.; Keshavarzian, A. The gastrointestinal microbiome: Alcohol effects on the composition of intestinal microbiota. Alcohol Res. 2015, 37, 223-236. [PubMed]

118. Elamin, E.; Masclee, A.; Troost, F.; Dekker, J.; Jonkers, D. Activation of the epithelial-to-mesenchymal transition factor snail mediates acetaldehyde-induced intestinal epithelial barrier disruption. Alcohol. Clin. Exp. Res. 2014, 38, 344-353. [CrossRef] [PubMed]

119. Davis, B.T.; Voigt, R.M.; Shaikh, M.; Forsyth, C.B.; Keshavarzian, A. CREB protein mediates alcohol-induced circadian disruption and intestinal permeability. Alcohol. Clin. Exp. Res. 2017, 41, 2007-2014. [CrossRef] [PubMed]

120. Tang, Y.; Forsyth, C.B.; Farhadi, A.; Rangan, J.; Jakate, S.; Shaikh, M.; Banan, A.; Fields, J.Z.; Keshavarzian, A. Nitric oxide-mediated intestinal injury is required for alcohol-induced gut leakiness and liver damage. Alcohol. Clin. Exp. Res. 2009, 33, 1220-1230. [CrossRef] [PubMed]

121. Forsyth, C.B.; Shaikh, M.; Bishehsari, F.; Swanson, G.; Voigt, R.M.; Dodiya, H.; Wilkinson, P.; Samelco, B.; Song, S.; Keshavarzian, A. Alcohol feeding in mice promotes colonic hyperpermeability and changes in colonic organoid stem cell fate. Alcohol. Clin. Exp. Res. 2017, 41, 2100-2113. [CrossRef] [PubMed]

122. Xu, M.; Wang, S.; Qi, Y.; Chen, L.; Frank, J.A.; Yang, X.H.; Zhang, Z.; Shi, X.; Luo, J. Role of MCP-1 in alcohol-induced aggressiveness of colorectal cancer cells. Mol. Carcinog. 2016, 55, 1002-1011. [CrossRef] [PubMed]

123. Chen, D.; Zhang, F.; Ren, H.; Luo, J.; Wang, S. Role of cytokines and chemokines in alcohol-induced tumor promotion. OncoTargets Ther. 2017, 10, 1665-1671. [CrossRef] [PubMed]

124. Hammer, A.M.; Morris, N.L.; Earley, Z.M.; Choudhry, M.A. The first line of defense: The effects of alcohol on post-burn intestinal barrier, immune cells, and microbiome. Alcohol Res. Curr. Rev. 2015, 37, 209-222.

125. Tsuchimoto, Y.; Asai, A.; Tsuda, Y.; Ito, I.; Nishiguchi, T.; Garcia, M.C.; Suzuki, S.; Kobayashi, M.; Higuchi, K.; Suzuki, F. M2b monocytes provoke bacterial pneumonia and gut bacteria-associated sepsis in alcoholics. J. Immunol. 2015, 195, 5169-5177. [CrossRef] [PubMed]

126. Roelands, J.; Kuppen, P.J.K.; Vermeulen, L.; Maccalli, C.; Decock, J.; Wang, E.; Marincola, F.M.; Bedognetti, D.; Hendrickx, W. Immunogenomic classification of colorectal cancer and therapeutic implications. Int. J. Mol. Sci. 2017, 18. [CrossRef] [PubMed]

127. Patel, S.; Behara, R.; Swanson, G.R.; Forsyth, C.B.; Voigt, R.M.; Keshavarzian, A. Alcohol and the intestine. Biomolecules 2015, 5, 2573-2588. [CrossRef] [PubMed]

128. Bishehsari, F.; Saadalla, A.; Khazaie, K.; Engen, P.A.; Voigt, R.M.; Shetuni, B.B.; Forsyth, C.; Shaikh, M.; Vitaterna, M.H.; Turek, F.; et al. Light/dark shifting promotes alcohol-induced colon carcinogenesis: Possible role of intestinal inflammatory milieu and microbiota. Int. J. Mol. Sci. 2016, 17. [CrossRef] [PubMed]

129. Abdelmegeed, M.A.; Banerjee, A.; Jang, S.; Yoo, S.H.; Yun, J.W.; Gonzalez, F.J.; Keshavarzian, A.; Song, B.J. CYP2E1 potentiates binge alcohol-induced gut leakiness, steatohepatitis, and apoptosis. Free Radic. Biol. Med. 2013, 65, 1238-1245. [CrossRef] [PubMed]

130. Shukla, P.K.; Chaudhry, K.K.; Mir, H.; Gangwar, R.; Yadav, N.; Manda, B.; Meena, A.S.; Rao, R. Chronic ethanol feeding promotes azoxymethane and dextran sulfate sodium-induced colonic tumorigenesis potentially by enhancing mucosal inflammation. BMC Cancer 2016, 16, 189. [CrossRef] [PubMed]

131. Voigt, R.M.; Forsyth, C.B.; Keshavarzian, A. Circadian disruption: Potential implications in inflammatory and metabolic diseases associated with alcohol. Alcohol Res. 2013, 35, 87-96. [PubMed]

132. Summa, K.C.; Voigt, R.M.; Forsyth, C.B.; Shaikh, M.; Cavanaugh, K.; Tang, Y.; Vitaterna, M.H.; Song, S.; Turek, F.W.; Keshavarzian, A. Disruption of the circadian clock in mice increases intestinal permeability and promotes alcohol-induced hepatic pathology and inflammation. PLoS ONE 2013, 8, e67102. [CrossRef] [PubMed]

133. Preuss, F.; Tang, Y.; Laposky, A.D.; Arble, D.; Keshavarzian, A.; Turek, F.W. Adverse effects of chronic circadian desynchronization in animals in a "challenging" environment. Am. J. Physiol. Regul. Integr. Comp. Physiol. 2008, 295, R2034-R2040. [CrossRef] [PubMed] 
134. Morimoto, L.M.; Newcomb, P.A.; Ulrich, C.M.; Bostick, R.M.; Lais, C.J.; Potter, J.D. Risk factors for hyperplastic and adenomatous polyps: Evidence for malignant potential? Cancer Epidemiol. Biomark. Prev. 2002, 11, 1012-1018.

135. Erhardt, J.G.; Kreichgauer, H.P.; Meisner, C.; Bode, J.C.; Bode, C. Alcohol, cigarette smoking, dietary factors and the risk of colorectal adenomas and hyperplastic polyps-A case control study. Eur. J. Nutr. 2002, 41, 35-43. [CrossRef] [PubMed]

136. Giovannucci, E.; Rimm, E.B.; Ascherio, A.; Stampfer, M.J.; Colditz, G.A.; Willett, W.C. Alcohol, low-methionine-low-folate diets, and risk of colon cancer in men. J. Natl. Cancer Inst. 1995, 87, 265-273. [CrossRef] [PubMed]

137. Kune, G.A.; Vitetta, L. Alcohol consumption and the etiology of colorectal cancer: A review of the scientific evidence from 1957 to 1991. Nutr. Cancer 1992, 18, 97-111. [CrossRef] [PubMed]

(C) 2018 by the authors. Licensee MDPI, Basel, Switzerland. This article is an open access article distributed under the terms and conditions of the Creative Commons Attribution (CC BY) license (http://creativecommons.org/licenses/by/4.0/). 